\title{
Notes
}

\section{Canada Lynx, Lynx canadensis, Use of the Chignecto Isthmus and the Possibility of Gene Flow between Populations in New Brunswick and Nova Scotia}

\author{
Colin M. MacKinnon and AndRew C. Kennedy \\ Environment Canada, Canadian Wildlife Service, Atlantic Region, P. O. Box 6227, Sackville, New Brunswick E4L 1 G6 \\ Canada
}
MacKinnon, Colin M. and Andrew C. Kennedy 2008. Canada Lynx, Lynx canadensis, use of the Chignecto Isthmus and the possibility of gene flow between populations in New Brunswick and Nova Scotia. Canadian Field Naturalist 122(2): 166-168.

\begin{abstract}
An observation of tracks made by Canada Lynx on the Chignecto Isthmus supports assumed use of this area between New Brunswick and Nova Scotia as a potential wildlife corridor. Use of the isthmus by lynx may facilitate gene flow between otherwise geographically separate populations in Nova Scotia and New Brunswick.
\end{abstract}

Key Words: Canada Lynx, Lynx canadensis, Chignecto Isthmus, wildlife corridor, gene flow, New Brunswick, Nova Scotia, Missaguash Marsh.

The eastern Maritime Provinces of New Brunswick and Nova Scotia are connected by a narrow strip of land (24 km wide) known as the Chignecto Isthmus (Trueman 1896; Ganong 1903). The isthmus is bordered to the west by Cumberland Basin at the head of the Bay of Fundy and to the east by Baie Verte which opens into the Northumberland Strait. The area between these two bodies of water is predominantly composed of dykelands (saltmarshes converted to agricultural lands), freshwater lakes and bogs (the Missaguash Marsh), uplands comprised of mixed coniferous and deciduous woods, and scattered open farmland and dwellings. The actual boundary between the two provinces lies across this isthmus, following the Missaguash River $18.5 \mathrm{~km}$ to its head then overland to the Tidnish River (Figure 1). The Chignecto Isthmus is of particular interest as it is the only land bridge connecting Nova Scotia with continental North America and, in the $20^{\text {th }}$ century, at least three large mammals have entered the province via this route (Scott and Hebda 2004).

On the New Brunswick side of the Missaguash River a major highway (Route No. 16) divides the isthmus (a distance of $18.5 \mathrm{~km}$ ) and connects the villages of Aulac and Baie Verte. Farms and associated large open fields, as well as a number of dwellings, dominate the landscape on both sides of Route 16 except for a narrow $2.5 \mathrm{~km}$ strip of densely forested land at the head of the Missaguash Marsh (elevation $20 \mathrm{~m}$ ), where woodlands border both sides of the highway right-of-way. This highway is also one of the main transportation corridors connecting the Trans Canada Highway (Route No. 1) at Aulac with the Confedera- tion Bridge and Prince Edward Island. With the exception of the above mentioned forested area, this busy road, combined with the adjacent residential properties and the large expanses of open fields, is likely a barrier to movement of some species of wildlife across the isthmus.

On 12 February 2007, 11:30 am, we recorded tracks of a Canada Lynx, Lynx canadensis, crossing a densely wooded section of Route 16 (45 $\left.59^{\prime} \mathrm{N}, 64^{\circ} 09^{\prime} \mathrm{W}\right)$ at the head of the Missaguash Marsh, $16.3 \mathrm{~km}$ east of Aulac, New Brunswick (elevation $17 \mathrm{~m}$ ). Based on these tracks, the lynx had been moving through dense mixed woods in an area immediately adjacent to the north side of the road. The animal then crossed the road perpendicular to the highway where it immediately headed in a southerly direction, into dense woods, towards Nova Scotia. The tracks were believed to be less than 24 hours old and probably made during the night of 11/12 February 2007. The imprints were distinct with a clear foot impression measuring $7.5 \times 7.5$ $\mathrm{cm}$. A walking stride, the distance between footprints of the same foot, ranged from 61 to $71 \mathrm{~cm}$. The tracks were not followed into the woods due to insufficient time. Snow depth was about $25 \mathrm{~cm}$ with light accumulation made the night before. The last significant snowfall $(9.8 \mathrm{~cm})$ was recorded on 3 February, nine days previous to our survey.

The significance of this observation is twofold. First, this evidence of lynx activity emphasizes the importance of the Chignecto Isthmus, especially the remaining densely wooded area at the headwaters of the Missaguash River, as a wildlife corridor between the two provinces. Secondly, this sighting has implications 


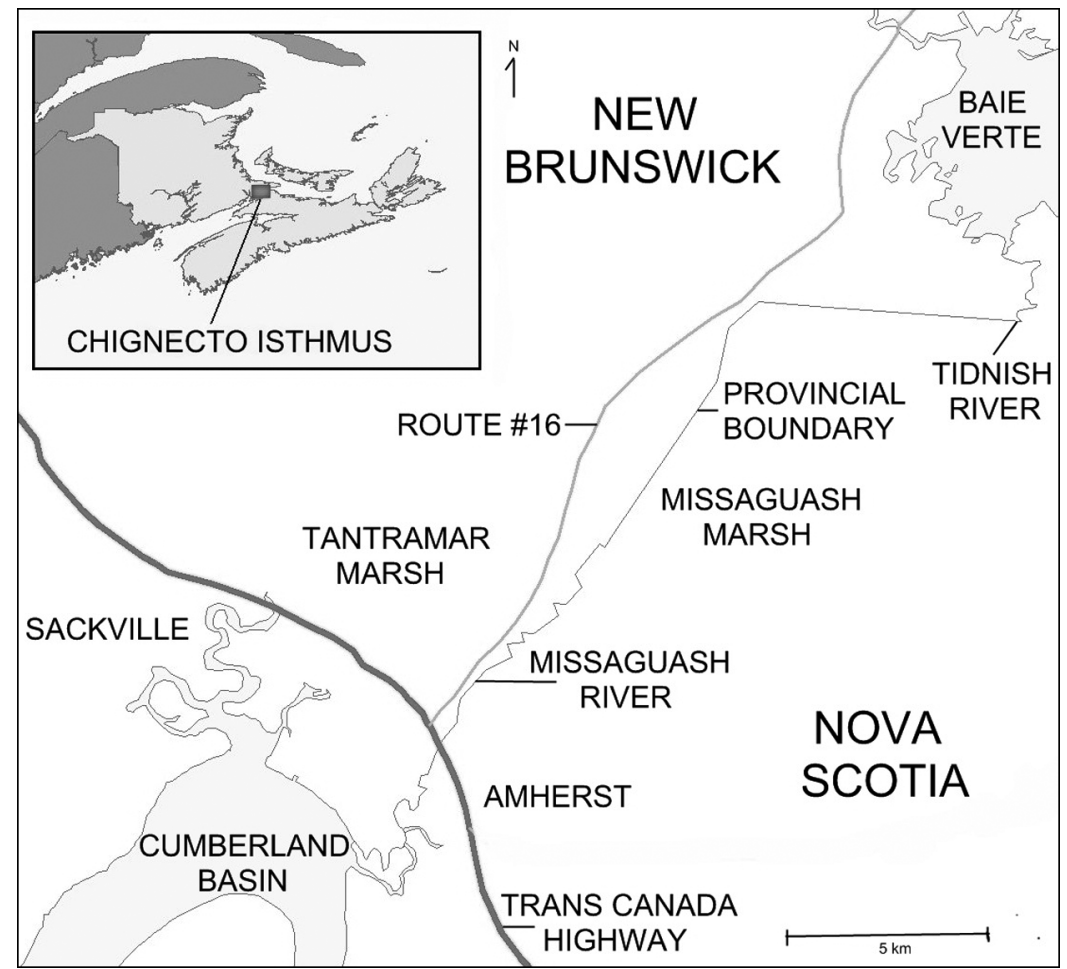

FIGURE 1. Place names and salient features on the Chignecto Isthmus.

regarding lynx management in Nova Scotia and supports the possibility of gene flow between that province and the nearest known breeding population in northwestern New Brunswick.

A wildlife corridor is a protected route that allows wildlife to move safely between areas of suitable habitat (Wilson and Willis 1975). The Chignecto Isthmus, being the only land connection between Nova Scotia and New Brunswick, has long been recognized by biologists, hunters and naturalists as serving a connectivity function for wildlife between the two provinces although no studies have been done to support this assumption. Large, widely ranging carnivores such as American Black Bear, Ursus americanus, and lynx are often used as a measure of the value of a possible wildlife corridor. This suggests that, if the needs of the more shy and secretive large mammals are met, so would be those of the smaller but equally important species (Parks Canada 2003*). Thus, this reporting of a single lynx track may have broad significance.

Canada Lynx was listed as endangered in Nova Scotia in 2002. In New Brunswick it was listed as endangered in 1976 and when the New Brunswick Endangered Species Act was revised in 1996, the lynx was listed as regionally endangered; i.e., in danger of dis- appearing in New Brunswick but remaining healthy elsewhere (Libby $2002^{*}$ ). For the past 40 or 50 years the breeding population of lynx in Nova Scotia has been restricted to the Highlands of Victoria and Inverness Counties, Cape Breton (Banfield 1974; Parker 1981; Parker et al. 1983), although, on occasion, occurrences have been reported on mainland Nova Scotia (Parker 2001*). In New Brunswick, lynx are restricted to the extreme northwest with only occasional sightings and trapping recoveries in the southeast (Cumberland et al. 1998: Parker 2001* and Libby 2002*). Any such overland movement between New Brunswick and Nova Scotia would have to be through the Chignecto Isthmus and, prior to our observation, we know of no previously documented lynx occurrence in this region. Donald Colpitts, a retired Forest Ranger with the New Brunswick Department of Natural Resources and Wildlife Technician for the Canadian Wildlife Service, has trapped furbearers on the isthmus and surrounding marshes for over fifty years. He also operated a trap-line in British Columbia and can readily differentiate tracks of lynx from those of similar sized mammals such as Bobcat, Lynx rufus, Red Fox, Vulpes vulpes, or Eastern Coyote, Canis latrans. He has never observed tracks of Canada Lynx on the Chignecto 
Isthmus (D. W. Colpitts, personal communication). Although the frequency of lynx crossing the Chignecto Isthmus are probably very low, there have been recent reports of tracks and sightings in southeastern New Brunswick (C. Libby, personal communication) and one animal was accidentally snared in November 1987 near Hopewell Cape in Albert County (McAlpine and Heward 1993), only approximately $36 \mathrm{~km}$ west of our observations.

Long distance travel by lynx may be quite common. Poole (1997) reported that lynx in the Northwest Territories travelled an average of $163 \mathrm{~km}$ during the first winter following a Snowshoe Hare (Lepus americanus) decline and Schwartz et al. (2002) demonstrated high gene flow between widely separate lynx populations (greater than $3100 \mathrm{~km}$ ) in northwestern North America. Our observations confirm the potential for lynx to cross the isthmus, between the two provinces, and would allow for gene flow between the breeding populations on Cape Breton Island and northwestern New Brunswick. As supported by our observation, the densely forested land, at the headwaters of the Missaguash Marsh on the Chignecto Isthmus, still holds potential as a wildlife corridor for inter-provincial movement of large secretive carnivores such as lynx. The maintenance of this corridor is important so that lynx on Cape Breton Island do not become genetically isolated but remain part of the greater North American population. Conservation of this area and its forested habitat may facilitate the continued use of the isthmus as a wildlife corridor for many species, including lynx, and thus limit the effect of land use changes that could hinder such movement.

\section{Acknowledgments}

We thank Peter Hicklin and Peter Austin-Smith Jr. for reviewing the manuscript. We also acknowledge assistance and advice from Cade Libby, Mike O'Brien and Gerry Parker in the preparation of this paper. Personal communications from D. W. Colpitts (Wildlife Technician - retired, 500 Route 16, Point de Bute, New Brunswick E4L 2N1) and C. Libby (Wildlife Biologist, Fish and Wildlife Branch, New Brunswick Department of Natural Resources, P. O. Box 6000, Fredericton, New Brunswick E3B 5H1) have been much appreciated. Finally, we thank the three anonymous reviewers for useful comments and recommendations.
Documents Cited (marked * in text)

Libby, Cade. 2002. Status of Lynx in New Brunswick. Fact Sheet, Wild Cat News, www.cougarnet.org

Parker, G. R. 2001. The Canada Lynx in Nova Scotia. Internal Report, Nova Scotia Species at Risk Working Group, 53 pages.

Parks Canada. 2003. Wildlife Corridors - a 'Moving' Story. Fact Sheet, Banff National Park, Box 900, Banff, Alberta, T1L $1 \mathrm{~K} 2$

\section{Literature Cited}

Banfield, A. W. F. 1974. The Mammals of Canada. National Museum of Natural Sciences, National Museums of Canada, University of Toronto Press. 438 pages.

Cumberland, R., R. Doucette, and T. Byers. 1998. A Historical Perspective of Canada Lynx (Lynx canadensis) in New Brunswick. Furbearer Report (19), Department of Natural Resources \& Energy, Fish \& Wildlife Branch, Fredericton, New Brunswick. 15 pages.

Ganong, W. F. 1903. The vegetation of the Bay of Fundy salt and diked marshes: an ecological study. Botanical Gazette: 36: 161-186, 280-349, and 350-455, Published by the University of Chicago, Chicago, Illinois.

McAlpine, D. F., and A. D. B. Heward. 1973. Lynx in New Brunswick. Chickadee Notes (5), New Brunswick Museum, Saint John, New Brunswick. 3 pages.

Parker, G. R. 1981. Winter habitat use and hunting activities of Lynx (Lynx canadensis) on Cape Breton Island, Nova Scotia. Pages 221-248 in Proceedings of the Worldwide Furbearer Conference. 1980. Edited by J. A. Chapman and D. Pursley. Frostburg, Maryland.

Parker, G. R., J. W. Maxwell, L. D. Morton, and G. E. J. Smith. 1983. The ecology of the lynx (Lynx canadensis) on Cape Breton Island. Canadian Journal of Zoology 61: 770-786.

Poole, K. G. 1997. Dispersal patterns of Lynx in the Northwest Territories. Journal of Wildlife Management 61: 494505.

Schwartz, M. K., L. S. Mills, K. S. McKelvey, L. F. Ruggiero, and F. W. Allendorf. 2002. DNA reveals high dispersal synchronizing the population of Canada Lynx. Nature 415: 520-522.

Scott, F. W., and A. J. Hebda. 2004. Annotated list of the mammals of Nova Scotia. Proceedings of the Nova Scotia Institute of Science 42: 189-208.

Trueman, G. J. 1896. The marsh and lake region at the head of Chignecto Bay. Pages 92-104 in Bulletin of the Natural History Society of New Brunswick.

Wilson, E. O., and E. O. Willis. 1975. Applied biogeography. Pages 522-534 in Ecology and Evolution of Communities. Edited by M. L. Cody and J. M. Diamond. Belknap Press, Harvard University, Cambridge, Massachusetts.

Received 20 November 2007

Accepted 15 April 2009 